\title{
„Városi világ”: Enyedi György globális urbanizációs elmélete (Egy személyes hangvételü írás)
}

\section{"Urban world": György Enyedi's global urbanisation theory (A personal account)}

\author{
SZIRMAI VIKTÓRIA
}

Talán nem véletlen, hogy a külföldi útjaimon mindig eszembe jut Enyedi György globális urbanizációs elmélete. Hiszen oly sokszor elemezte mértani pontossággal a különböző nyugat-európai országok nagy térbeli folyamatait, azok történeti változásait, az amerikai társadalomban már az 1920-as, 1930-as években érvényesülő urbanizációs szakaszok európai megvalósulását, a nyugat-európai fejlett országokban szerveződött gazdasági, társadalmi és politikai erők kisugárzását, közte közép-európai hatásait, a centrum, a periféria és a félperiféria egyenlőtlen viszonyát.

Egy svájci körutazás keretében, ahol módom volt számos svájci nagyvárost megnézni, ráéreztem - a látottak és a hallottak alapján is -, hogyan lesz számos történeti folyamat során egy (végül is kicsiny) országból centrumország. Először jártam Svájcban, és a látottakat kevésbé a szokásos turisztikai közhelyekkel vetettem egybe. Kevésbé figyeltem a mindennapi, sokszor sommás ítéletekre, amelyek a valóságban vélhetőleg sokkal differenciáltabbak, mint a megfogalmazott megállapítások. Nem igazán akartam empirikusan ellenőrizni, hogy a svájci emberek valóban unalmasak vagy sem, és azt sem, hogy túlzott vagy sem a városokban, a közintézményekben, az utcákon lévő rend és tisztaság. De a pozitív, sommás dicsérő véleményeket sem igazán akartam vizsgálni, azt sem, amit sokan nagyra értékelnek, hogy itt minden tökéletesen müködik (ez utóbbi az adott turistaút esetében valóban igaznak bizonyult). Ami érdekelt, és amire valóban figyeltem, az a centrumországgá válás folyamatának a rejtélye, az a kérdés, hogyan vált ez az ország olyanná, amely a világ más országaira is hatást gyakorol és ahonnan (is) a globalizáció egyes folyamatai kiindulnak.

Egy turistaút persze erre a nagy kérdésre kevéssé képes választ adni, de mégis arra inspirált, hogy Enyedi György globális urbanizációs elmélete alapján nézzek körül a városokban, és próbáljam megérteni fejlődésük, gazdagságuk okait. Az út során kiderültek a fő meghatározó tényezők: az, hogy ez az ország

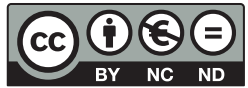


történetileg mindig kihasználta a természeti, környezeti adottságait; ha szükség volt rá, épített azokra. Így a térség sajátos zártsága, hegyvidéki jellege adta az ország biztonságát, de az Alpokon való átjárhatóság infrastrukturális kiépítése is fontos volt, hiszen történetileg ez teremtette meg a gazdagság alapjait. A társadalmi jellegzetességek, a demokratikus polgári kultúra, a helyi emberek (közte a véleményhordozók és a vezetők) elszántsága az ország lokális érdekeinek védelméért szintén fontos tényezők. De a társadalom szinte minden szereplőjére jellemző, történetileg is innovatív gondolkodásmód, a gazdasági, a társadalmi és a politikai potenciál szinte teljes körű kihasználása, a törekvés a modernizációra - annak kevésbé a befogadására, inkább indítására -, az új (termékek, gondolatok stb.) létrehozatala együttesen hozták létre a centrumszerepek rendszereit, a kisugárzó erőt. Városaikban érződik a történelem, a protestáns etika, annak építészeti következményei miatt is visszafogottabb városi atmoszféra. (Még a globális Zürich városán is meglepődik az odaigyekvő külföldi, hiszen a magas felhőkarcolók helyett alacsonyabb, tömör, egyszerü épületeket lát.) A német, az olasz, a rétoromán, a francia városok persze igen eltérőek. (Az utóbbiak esetében úgy láttam, hogy a svájci visszafogottság jól ötvöződik a francia eleganciával.) De a lényeg mindenhol a modern, a globális és a történeti hatások sajátos egyvelegének a jelenléte.

Enyedi György a globalizációt főként az urbanizációs jelenségeken keresztül mutatta be, globális urbanizációs elméletét több munkájában is olvashattuk, elsőként A városnövekedés szakaszai című művében (Enyedi 1988). Az utóbbi időszakban a Tér és Társadalomban, angolul pedig az Urban sprawl in Europe kötetben is megjelent erről írása (Enyedi 2011a, 2011b). Ezt az elméletet a legtisztább formában utolsó művében, a Városi világ címü könyvben olvashatjuk (Enyedi 2012).

A könyvét méltató egy korábbi írásom (Szirmai 2012), amely ennek a munkámnak a gerincét adja, 2012 októberében, Párizsban készült, ahol két hónapos kutatói ösztöndíj keretében tartózkodtam. Ez számomra nehéz időszak volt, részben azért, mert távol voltam a családomtól, a barátaimtól, a közvetlen kollégáimtól. Jóllehet ott is nagyon sok barátom van, számos olyan kedves francia kollégámmal is találkoztam, akikkel különböző projektekben hosszú évek óta együtt dolgoztam. De mégis nehéz volt, és legfőképp azért, mert azt hiszem, ott búcsúztam el igazán Enyedi Györgytől, a mesteremtől, a barátomtól.

Bevallom, hosszú ideig nem tudtam elolvasni a könyvet. Ezért sem vállaltam el Enyedi professzor halálát követően Barta Györgyi azon felkérését, hogy a Tér és Társadalom számára írjak a fenti könyvről recenziót. A professzor 2012. szeptember 10-én halt meg. Halálának egyéves évfordulóján a rá emlékezni kívánó Tér és Társadalom föszerkesztőjének felkérését most azonban elfogadtam, mégpedig azért, mert már tudomásul vettem az elfogadhatatlant, és ezzel a személyes hangvételü írással is rá emlékezem.

A könyvet akkor azért nem tudtam elolvasni, mert éreztem, hogy nehéz lesz a gondolatait úgy követni, a szöveget úgy olvasni, hogy nem hívhatom fel 
többé, hogy nem beszélhetem meg vele, hogy ez most milyen jó vagy éppen vitatható. Mert vitázni is lehetett vele, odafigyelt a másik szempontjaira. Egy ízben, mikor megköszöntem a segítségét valamilyen munkám vagy éppen közös írásunk, közös könyvünk kapcsán, azt mondta, én is tanultam tőled.

Én nagyon sokat tanultam tőle. Az ő hatására másképp látom például a tér és a társadalom kapcsolatát, mint amikor hosszú évekkel azelőtt megismerkedtünk, de időközben az ő véleménye is változott. Egy szakmai vita keretében találkoztunk, talán az 1980-as évek elején, mindketten meghívottak voltunk. A beszélgetés fó témájára már nem igazán emlékszem, de a lakóhely társadalmi jelentőségéről biztos, hogy szó esett. A vita során az ő véleménye az volt, hogy a lakóhely a társadalmi magatartás legfontosabb változója, én viszont úgy gondoltam, hogy a társadalmi strukturális helyzet fontosabb meghatározó tényező. (Az álláspontjával vitázó nézetemet később le is írtam.) Az évek alatt, közös munkáink során azonban közeledett a két vélemény egymáshoz, és mind a ketten a korábbinál sokkal komplexebben, egymásra gyakorolt hatásaik alapján elemeztük a tér és a társadalom viszonyát. Hogy a felfogásbeli közeledésben volt-e szerepem vagy sem, valójában nem fontos. Ami fontos, hogy Enyedi György - bár közgazdász és geográfus volt, de - első helyet foglalt el azon közgazdászok és geográfusok között, akik erős társadalmi szemlélettel rendelkeztek, akik a teret társadalmi egységként fogták fel, s akik mindig tudták, a területi folyamatok egyben társadalmi folyamatok is.

Alapvetően egy véletlen hozta, hogy közösen kezdtünk dolgozni, hogy tanulhattam tőle. 1988-ban jelent meg a Gyorsuló idő sorozatban a „Csinált” városok címü könyvem (Szirmai 1988). Akkoriban még nem szerveztem könyvbemutatót, vagy azért, mert bizonytalan voltam a könyv lehetséges sikerében, vagy azért, mert nem volt divat, már nem tudom. Ezért néhány közeli kollégának postán küldtem egy-egy példányt. A professzor azonban abban az időben nem volt Magyarországon, kutatóprofesszorként egy hosszabb, egyéves kutatói tanulmányúton vett részt Washingtonban, a Smithsonian Intézetben. Én pedig bizonytalan voltam abban, hogy mit tegyek a könyvvel, elküldjem vagy ne küldjem el neki. Féltem, ha elküldöm, nagyzolónak fog tartani vagy zavarni fogom a munkámmal; vagyis egyáltalán nem ismertem őt mint embert, és persze valószínűleg a könyvem értékeit sem igazán láttam. Végül (szerencsére) a postára adás mellett döntöttem. Nem is sokára egy levelet kaptam tőle. (Sajnos nem tettem el, néha az ember nem tudja, milyen levelek az igazán fontosak az életben, közte a szakmai karrier történetében is.) Ebben a levélben megírta, hogy tetszett neki a könyvem, és kért, hogy legyek társszerzője egy Budapestről szóló angol nyelvü könyvnek, amelynek a megírására akkor kapott kiadói felkérést. Ez a könyv el is készült, meg is jelent (Enyedi, Szirmai 1992). Ezt a könyvet még számos közös munka, közös publikációk sora és a két család közötti barátság követte.

Mindig megtisztelt azzal, hogy a fontosabb szakmai eseményeimre eljött, bemutatta az akkor megjelenő könyvemet vagy az általam szerkesztett köteteket (ilyenek voltak: Szirmai 1999, 2009, 2010). Az Urban sprawl in Europe címü kö- 
tetet bemutató budapesti konferencián is rész vett (2011. november 18-án), ahol egy elméleti előadást tartott a globális urbanizáció fő szakaszairól.

A velem dolgozó fiatal kollégáimat is segítette: az általam vezetett (akkori nevén) MTA RKK székesfehérvári csoport egyik munkatársa, Baráth Gabriella - aki ún. co-tutelle keretében Françoise Plet professzorasszony (aki szintén Enyedi-tanítványnak vallja magát) és az én doktoranduszom volt - pécsi PhD-védésére is eljött, mint a bizottság elnöke. Berki Mártonnak már nagyon betegen adott meleg ajánlást, hogy megpályázhassa az MTA TK Szociológiai Intézeténél kiírt fiatal kutatói posztot (amelyet sikeresen meg is kapott). A lányomat, Schuchmann Júliát már kislány kora óta ismerte és mindig támogatta geográfus pályaválasztását, a doktori témájához tanácsokat is nyújtott neki (Schuchmann 2012).

Utoljára a Városi világ címü könyvének akadémiai bemutatóján találkoztam vele (2012. július 5-én). Előtte még telefonon beszéltünk. Akkor már nagyon beteg volt, ezért is tartott attól, hogy nem fogja tudni végigcsinálni a bemutatót, ahogy mondta, az utolsót. Én ezt nem akartam, nem tudtam elfogadni. A beszélgetés során végül is abban maradtunk, jó, több könyvet már valószínűleg nem ír, hiszen ez összefoglalója eddigi tudásának (ő legalábbis ezt állította), de azért tanulmányai még lesznek. Ezt az ígéretét sajnos nem tartotta be, a sikeres könyvbemutató után nemsokára végleg elment, orvosi értelemben, mert beteg volt, spirituálisan pedig valószínủleg elfáradt már. De az is lehet, hogy úgy látta, már mindent átadott nekünk. És hogy ideje, hogy felnőjünk mi is, a következő, ha nem is olyan nagy generáció, mint az övé volt, de képzett nemzedék, olyan, amelynek tagjai immár maguk is a fiatalok mentorai lehetnek.

Bárhogy is volt, nem hagyott elvarratlan szálakat. Ebben a könyvben, amelyet utolsó művének nevezett (s amelyet a rá jellemző humorral nem hattyúdalnak titulált, mert ,a hattyúnak szerfölött ronda a hangja”) városföldrajzi-urbanisztikai tanulmányait foglalta össze. Az érdeklődő olvasó - beleértve a szakembereket, az egyetemistákat, a doktoranduszokat - nem csupán képet kapnak szinte minden fontos, várossal összefüggő kérdésben, hanem elképesztő, hatalmas tudásmennyiséggel is találkozhatnak egy nemzetközileg is kiemelkedő, otthon és külföldön is méltán szeretett és tisztelt tudós könyvéből.

Ezt a szeretetet és tiszteletet láttam és éreztem Párizsban is, ahol 2012. november 21-én francia barátai, régi kollégái a Párizs8 egyetemen, a geográfiai tanszék szervezésében egy rá emlékező találkozót szerveztek. Nagyon sokan eljöttek és sokan beszéltek róla, közte olyan barátai, akikkel éveken keresztül együtt dolgozott (ilyen volt Françoise Plet és Nicole Mathieu professzorok vagy Marie-Claude Morel, az Institut Universitaire de France egyik vezetője). Engem arra kértek, hogy vezessem be az emlékező délutánt és beszéljek arról, milyen hatással volt Enyedi György a munkáimra, valamint mutassam be legutolsó könyvét. Ezt meg is tettem (a PowerPoint előadást a socio.hu 2012. évi egyik számában meg is lehet nézni).

Ott is elmondtam, ahogy most itt is leírom: ez a könyv egyértelműen arra törekszik, hogy összefoglaljon mindent, amit szerzője eddig olvasott, látott, ku- 
tatott, és hogy adjon egy általános, átfogó képet a „városi világról”. Amely ugyan sokrétü és történetileg igencsak változó, de a nagy folyamatai alapján is leírható. A könyvből kiderül, hogy a professzor egyik város, egyik várostérség iránt sem elfogult, nincsen kiemelten elemzett térség: az amerikai, a latinamerikai, az európai, az afrikai, az ázsiai, az orosz, a japán és persze a magyar városokról egyaránt ír. (Pedig tudom, hogy Párizs volt a kedvenc külföldi városa, mert egyszer megkérdeztem tőle, és nem túl hosszú gondolkodás után ez volt a válasza.)

Enyedi György többször is kiemeli, hogy célja az általános folyamatok összefoglalása és bemutatása, ezért nem használ mindent alátámasztó, bizonyító statisztikákat, nincsenek statisztikai táblák, csak néhány alapvető térképet, összegző statisztikai adatot találhatunk. Mégsem mondanám, hogy a kötet elméleti mű, sokkal inkább empirikus, még akkor is, ha nincsenek benne szociológiai jellegủ dokumentumok, táblázatok, csak a valóságos, empirikusan is tapasztalható folyamatok.

Számos irodalmi hivatkozás is megjelenik. Ezek a hivatkozások gyakran kritikai jellegüek. S Enyedi nemcsak saját szakterületének szakembereivel vitázik, de bírálja a város (például Budapest) sorsáért felelős szereplőket is. A Fővárosi Önkormányzatot azért, mert még mindig hiányzik a főváros jövőbeli európai szerepének megfogalmazása, annak stratégiája (Enyedi 2012, 35.). Az urbanisztika művelőit azért, mert „,nem mindig ismerik fel azokat a társadalmi folyamatokat, melyek a rossz lakásviszonyokat, a városon belüli társadalmi konfliktusokat eredményezik." (Enyedi 2012, 37.). De kritikája előremutató, a különböző szakterületek, illetve szakmák együttmüködését is támogatja, például azzal, amikor azt állítja, hogy az „urbanisztika a várostól nem alkothat egyoldalú képet, a városi térhasználat szempontjait össze kell hangolnia a városszociológia, az ingatlanpiac, a várospolitika, sőt - ez gyakran feledésbe merül - a városlakók szempontjaival (Enyedi 2012, 37.).

Ezt az is jelzi, hogy amikor a könyvben bemutatja, mi is a város és milyen „arculatokkal” rendelkezik, akkor a földrajzi, közgazdasági, történeti, demográfiai, közjogi, közigazgatási, urbanisztikai, természeti „arcok”, vagyis jellegzetességek mellett a város társadalmi arcát is megismerhetjük. Ebben többek között sorra veszi a társadalmi egyenlőtlenségek mérséklésére kialakított különböző szakmai és ideológiai koncepciókat, miközben vitatja is az urbanisták utópikus elképzeléseit, a neomarxizmus szempontjait, mondván, hogy erre a lényegi társadalmi problémára ők sem tudtak megfelelő válaszokat adni. Valószínűleg azért - $\mathrm{s}$ ezt a tények alapján magam is így gondolom -, mert a „piacgazdaság természetszerüleg újratermeli az egyenlőtlenségeket” (Enyedi 2012, 32.). Ezek az egyenlőtlenségek - közte a szegregáció is - diszkriminatív jellegük miatt elítélendők, s ma egész Európa így is tesz. Miközben messzemenően egyetértek a professzorral abban is, hogy a szegregáció nem mindig negatív jelenség. Minden korábbi munkámban, közte egy nemrég megjelent tanulmánykötetben is (Szirmai, Váradi 2013) azt az álláspontot képviselem, amelyet Enyedi György 
következő mondata is kifejez: „Úgy vélem, hogy a szegregáció egyfelől elválaszt (városnegyedeket), másfelől elősegíti az integrációt (a városnegyedeken belül)" (Enyedi 2012, 33.).

A könyv egyik fő súlypontja az urbanizációs folyamatok, a városnövekedés szakaszainak, azok tudományos előzményeinek bemutatása, amelynek keretében megtudjuk, hogyan lesz a helyi sajátosságokra épülő különböző (közte európai vagy éppen amerikai) modellekből világmodell, éppen Enyedi munkássága alapján. A világmodellség nála azt jelenti, hogy a jelzett periódusok az egész világon megjelentek, többnyire a fejlett országokból indultak ki, s terjedtek a perifériák, félperifériák felé. A világmodellség ideájából egy számunkra igen fontos szempont is következik, nevezetesen az, hogy nincs külön szocialista modell (Enyedi 2012, 57.).

Enyedi ezen utolsó könyve újragondolja a korábbi világmodell összetevőit, mert az önmagát mindig képző, a nagyvilággal folyamatos szakmai kapcsolatokat ápoló tudós időközben rájött, hogy az 1980-as évek óta, amikor a modellt megalkotta, sok minden megváltozott, új területi, társadalmi és gazdasági folyamatok jelentek meg, főként a globalizáció eredményeként. Ezért Enyedi kritikailag elemzi és újraértelmezi mind a történeti előzményeket, tehát az elmélete alapját adó holland iskola (van den Berg) által definiált periódusokat, mind saját korábbi világmodelljét. A holland iskola szerint az urbanizációt a szuburbanizáció, majd a dezurbanizáció és végül a reurbanizáció követi, amelyet a városok megújulásából fakadó tömeges visszaköltözés fog biztosítani. Ő azonban sem a reurbanizáció kifejezésével, sem annak tartalmával, sem a magyarázó folyamatokkal nem értett egyet. A „reurbanizáció kifejezést pontatlannak, sőt félrevezetőnek tartom" - állítja (Enyedi 2012, 70.). Szerinte a történelmi városközpontok megújulása, a napi ingázás nehézségei nem okoznak ismét városi tömörülést, nem eredményeznek tömeges visszaköltözést. Véleménye szerint a történelmi belvárosok újraéledése a városi agglomeráción belüli népesség átrendeződését és nem a visszaköltözést hozza magával (Enyedi 2012, 70.).

Az újracentralizációról (tehát ebben a kontextusban nem a reurbanizációról) már korábban is másképp gondolkodott. Az informatika rohamos fejlődése alapján úgy vélte, hogy nagymértékủ decentralizáció jön létre a területi szerkezetben. Itt Castellsre is hivatkozik, aki - hasonlóképpen, ahogy Enyedi az 1990-es évek elején - az informatikai rendszerek fejlődése alapján a szervezeti, irányítói tevékenység decentralizálódását prognosztizálta. De a tények mást mutattak, mégpedig azt, hogy a döntési, innovációs funkciók továbbra is a nagyvárosokban maradtak, tehát nem decentralizálódtak - magyarázza Enyedi. Saját koncepciójával kapcsolatban végül azt írja, hogy „tévedtem.” De ugyanezt gondolja Castells álláspontjáról is. A rá jellemző humorral hozzáteszi, hivatkozva Castellsre: „legalább jó társaságban tévedtem" (Enyedi 2012, 47.).

Az újragondolt negyedik szakasz a globalizált urbanizáció, amely talán a világmodell legújabb gondolata. Enyedi szerint a globalizált urbanizáció a mai világ új globális gazdasági folyamatait, a kapitalizmus világrendszerének teljes kibontakozását fejezi ki, amely az eredeti világmodell kimunkálásakor még nem 
volt teljes hatásában érzékelhető. Ezek a hatások pedig ismételt népességrobbanással jártak. „Az 1990-es évekre nem prognosztizáltam a nagyvárosok és a megavárosok újabb népességrobbanását" - ismeri el a szerző (Enyedi 2012, 58.).

Ez a szakasz, vagyis a globális hatások a világ minden részén megjelennek, azokon a helyeken is, ahol még az első három is érvényesül. De a szakaszok egymás utáni rendje, a földrajzi elterjedés folyamata már megváltozott, specifikálódott.

A gondolkodó, egyben kritikus szerző megemlíti, hogy az elődök igazából nem vizsgálták, hogy milyen lényegi erők hozzák létre az urbanizációs ciklusokat (jóllehet ez egy alapvető kérdés, hiszen ez magyarázza meg a történéseket). Ezzel kapcsolatban Enyedi is csupán hipotézist fogalmaz meg. Véleménye szerint a hosszú távú gazdasági ciklusok adják a modern urbanizációs ciklusok alakulásának meghatározó mechanizmusait (Enyedi 2012, 73.).

A könyvet olvasó érdeklődő részletes képet kap az egyes szakaszokról, a városrobbanás, a viszonylagos dekoncentráció, a dezurbanizáció, végül a globalizált urbanizáció jellegzetességeiről, a megjelenés időszakairól, az adott periódusra érvényes gazdasági ciklus sajátosságairól, a kapcsolódó társadalmi szerkezetekről és a politikai rendszer formáiról. Ezek közül fontosnak tartom kiemelni a társadalmi szerkezeti hatásokat, az első szakasz éles osztályelvü tagozódását, a második szakasz során izmosodó középosztályosodást, a harmadik szakaszban formálódó nem materiális értékek térhódítását, majd a globális szakasz regionális konfliktusait, éles társadalmi egyenlőtlenségeit.

Az utóbbiakkal kapcsolatban ismét csak tanultam tőle: a Párizs város tudományos tanácsához beadott és elnyert két hónapos kutatási ösztöndíj fó témája a párizsi és a budapesti régió társadalmi polarizációs viszonyainak a vizsgálata, a különbségek és a hasonlóságok feltárása volt. A kutatómunka során folyamatosan azzal a kérdéssel szembesültem, hogyan lehet ezt a két nagyon különbözö, eltérő méretű és funkciójú - Enyedi terminológiájával élve a 10 milliónál nagyobb párizsi megavárost (városrégiót), egy fejlett térség valódi globális városát a közép-európai, félperiférián található budapesti agglomerációval összehasonlítani, akárcsak egy tényező, vagyis a társadalmi polarizáció szempontjából.

Az Enyedi-féle világmodell-gondolat alapján volt módom arra, hogy megvédjem saját kutatási célomat, annak relevanciáját és elkészítsem a tanulmányt is (Szirmai 2012). Enyedi György szerint a városi társadalmak szegregációja - vagy éppen a társadalmi polarizációja - éppúgy világjelenség (Enyedi 2012, 67.), mint a többi kapcsolódó folyamat, éppúgy megnyilvánul minden térségben, megjelenik mindenhol, mint a városokat leíró többi tényező. Jóllehet különböző formában és mértékben, más és más történelmi tényezők kondicionáltsága alapján, a globális hatások eredője szerint. Ezért lehet csak a fö trendeket - a szerző szavaival élve -, az általánost keresni, és egyben tudni, hogy az általános folyamat mögött sok a különbség is.

A nemzetközi, azon belül a francia és a magyar városszociológiai, városföldrajzi szakirodalom tanúságtétele szerint a fö társadalmi polarizációs trendek egyértelműen hasonlóak. Hiszen hasonló a vizsgált két európai város- 
központ (a párizsi és a budapesti városmagok) kiemelt társadalmi státusa. (Az amerikai modell ettől eltérő, ott a városközpont alacsonyabb társadalmi értéket képvisel, mint az elővárosi sáv.) Minthogy hasonlónak bizonyult a két környék centrumhoz képest részben alárendelt társadalmi pozíciója, részben markáns differenciáltsága, magas és alacsonyabb társadalmi pozíciójú egységekre történő bomlása is.

A két várostérség magja, tehát Párizs és Budapest társadalomszerkezeti összevetését egyértelműen relevánsnak találtam, s nem is azért, mert a két település lakossága megközelítően azonos (2012-ben Párizsban 2243833 ember, Budapesten pedig ugyanebben az évben 1740041 fó élt), hanem föként azért, mert a két város belső társadalmi szabdaltságában erőteljesek a megfelelések. A párizsi „beaux quartiers” megfelelőit a magyar fóvárosban is megtaláljuk, ha nem is ugyanabban a tündöklésben és gazdagságban, mint ahogy a francia esetben. És akkor is megtaláljuk, ha a magyar kiemelten jó városnegyedek lakóinak magyar viszonylatban magas jövedelme meg sem közelíti a nyugat-európai város jobb negyedeiben élők jövedelmi körülményeit. A megfelelés akkor is megvan, ha a két város jobb negyedeiben az ingatlanárak, valamint ingatlanértékek jellemzőiben elképesztőek a különbségek.

Mert a lényeg az a társadalmi (jövedelmi, szakképzettségbeli) összetételbeli különbség, az a társadalomszerkezeti hierarchikus rend, amelyet mind a párizsi régió, mind pedig a budapesti térség esetében megtalálni: a jobb városrészek és a hátrányos helyzetű városnegyedek közötti eltérés. Ezt a sajátos társadalmi térbeli hierarchiát, annak különös hasonlóságát Nadine Cattan párizsi régiót bemutató tanulmányában, valamint a budapesti térség társadalmi szerkezetét ábrázoló esettanulmányban jól lehet látni (Cattan 2011; Szirmai, Váradi, Kovács, Baranyai, Schuchmann 2011).

Enyedi professzor a hasonlóságokat kereste, tette ezt azért, hogy bemutassa a magyar városok, a városi térségek, a hazai urbanizáció európai, egyben globális jellegét, amely ugyan éppen a történeti adottságok, a félperiferikus földrajzi helyzet miatt késleltetett, de egyben követő jellegű. Természetesen tudta, hogy az eltérések, a különbségek feltárása is fontos tudományos feladat. De ez az utolsó munka mégis főként az általánosra koncentrált, s talán nemcsak a szintéziskészítés igénye miatt, hanem azért is, hogy rámutasson arra, s a fiatalok figyelmét is felhívja rá, hogy legyünk büszkék az európaiságunkra. De ezt sajnos már nem tudjuk tőle megkérdezni, így ez az én feltevésem marad csupán.

\section{Irodalom}

Cattan, N. (2011): Urban sprawl in the Paris metropolitan area. In: Szirmai, V. (ed.): Urban sprawl in Europe. Aula Könyvkiadó, Budapest, 83-107.

Enyedi Gy. (1988): A városnövekedés szakaszai. Akadémiai Kiadó, Budapest 
Enyedi, Gy., Szirmai, V. (1992): Budapest. A Central European capital. Belhaven Press, London (World cities series)

Enyedi Gy. ( 2011a): A városnövekedés szakaszai - újragondolva. Tér és Társadalom, 1., 5-20.

Enyedi, Gy. (2011b): The stages of urban growth. In: Szirmai, V. (ed.): Urban sprawl in Europe. Aula Könyvkiadó, Budapest, 45-63.

Enyedi Gy. (2012): Városi világ. Akadémiai Kiadó, Budapest

Schuchmann J. (2012) Enyedi György emlékére. Egy fiatal geográfus személyes emlékei a Professzorról, a Példaképről és a Barátról. socio.hu, 4.

Szirmai V. (1988): „Csinált” városok. Magvető Kiadó, Budapest (Gyorsuló ido”)

Szirmai V. (1999): A környezeti érdekek Magyarországon. „Fontosabb, hogy megéljünk (?)” Pallas Stúdió, Budapest

Szirmai V. (2009): A várostérségi versenyképesség társadalmi tényezői. Dialóg Campus Kiadó, Budapest, Pécs

Szirmai V. (szerk.) (2010): Közép-Dunántúl. Dialóg Campus Kiadó, Budapest, Pécs

Szirmai, V. (ed.) (2011): Urban sprawl in Europe. Aula Könyvkiadó, Budapest

Szirmai, V., Váradi, Zs., Kovács, Sz., Baranyai, N., Schuchmann, J. (2011): Urban sprawl and its spatial, social consequences in the Budapest metropolitan region. In: Szirmai, V. (ed.): Urban sprawl in Europe. Aula Könyvkiadó, Budapest, 141-187.

Szirmai V (2012): Hommage Enyedi György professzornak. Recenzió. Enyedi György: Városi világ. socio.hu, 4.

Szirmai, V. (2012): Rapport final de recherche: „Polarisation socio-spatiale dans deux régions capitales européennes, celles de Paris et de Budapest: similarités et différences”. Paris. (Kézirat)

Szirmai V., Váradi Zs. (2013): Térbeli-társadalmi elkülönülés és integráció a magyar nagyvárostérségekben. In: Kovách I., Dupcsik Cs., P. Tóth T., Takács J. (szerk.): Társadalmi integráció a jelenkori Magyarországon. Argumentum Kiadó, Budapest, 115-132. 